\title{
Cancer Risk in Type 2 Diabetes Mellitus: Metabolic Links and Therapeutic Considerations
}

\author{
Grace Sun and Sangeeta R. Kashyap \\ Department of Endocrinology, Diabetes, and Metabolism, Cleveland Clinic, Cleveland, OH 44195, USA \\ Correspondence should be addressed to Sangeeta R. Kashyap, kashyas@ccf.org
}

Received 23 November 2010; Revised 10 February 2011; Accepted 24 March 2011

Academic Editor: Maria Luz Fernandez

Copyright ( $) 2011$ G. Sun and S. R. Kashyap. This is an open access article distributed under the Creative Commons Attribution License, which permits unrestricted use, distribution, and reproduction in any medium, provided the original work is properly cited.

Type 2 diabetes mellitus (DM2) is increasing in incidence, creating worldwide public health concerns and impacting morbidity and mortality rates. An increasing number of studies have demonstrated shared associations between DM2 and malignancy, including key clinical, biochemical, and metabolic commonalities. This paper will attempt to explore the relationship between the various types of cancer and diabetes, the common metabolic pathways underlying cancer development, and the potential impact of various antidiabetes therapies on cancer risk.

\section{Introduction}

The association between diabetes and cancer was described long before the 21st century, as far back as 1885 [1]. DM2 continues to increase in prevalence affecting 17.9 million Americans with 5.7 million undiagnosed, costing an estimated 174 billion healthcare dollars [2]. Cancer, second only to heart disease in mortality, is also on the rise with estimated costs in the US of $\$ 263.8$ billion [3]. These two high-impact diseases share factors which influence their development and progression, important in modifying each other's outcome.

1.1. Clinical Factors Underlying Cancer Risk. Common nonmodifiable (age, sex, and race/ethnicity) and modifiable (weight, diet, physical activity, tobacco use, and alcohol use) risk factors underlie the development of cancer and DM2. Figure 1(a) illustrates the general risk factors for cancer development in diabetes. It is known that both DM2 and cancer increase with age; those $\geq 55$ years comprise almost $80 \%$ of newly diagnosed cancers and $23.1 \%$ of patients $\geq$ 60 years develop DM2 compared to $10.7 \%$ of younger adults $[4,5]$. Men have slightly more cancer and diabetes compared to women after adjusting for other risks [4-6]. AfricanAmericans as a subgroup appear hardest hit with regards to cancer-related deaths, DM2, and obesity compared to non-Hispanic white counterparts $[4,5]$. Central obesity, a marker of insulin resistance and a key player in both DM2 and the metabolic syndrome, has also been linked to breast, colorectal, liver, and endometrial, malignancies [5]. Dietary choices high in glycemic load and saturated fat and low in fiber accompanied by reduced physical activity also increase the risk for DM2 and malignancy, particularly for the colon, endometrium and breast $[5,7]$. Moreover, studies show that tobacco and excess alcohol usage linked to cancer can also worsen diabetes complications [5].

1.2. Types of Cancers Linked to DM2 and Common Metabolic Pathways. Diabetes has been recognized as a key factor contributing to the development of solid organ malignancies including liver, pancreas, colorectal, breast, endometrial, uterine, and bladder $[3,5,8-18]$. The two cancers showing the strongest association to DM2 are those of the liver $[1,5,9,18-20]$ and pancreas $[1,5,18-20]$. Not only does there appear to be an association between DM2 and cancer, but having both diagnoses may increase mortality, regardless of the type of cancer $[9,21]$. Studies performed in Japan, Korea, and Hong Kong demonstrated increased cancer risk $[19,20,22]$ and mortality $[19,22]$ among participants with DM2, especially those with poorly controlled DM2 based on HbAlc [22] and fasting serum glucose levels [19]. A recent meta-analysis of 23 articles indicated a $41 \%$ increase in cancer mortality related to endometrial, breast, and colorectal cancer in patients with preexisting diabetes as compared to normoglycemic individuals [21]. In the American Cancer 
(a)

(b)

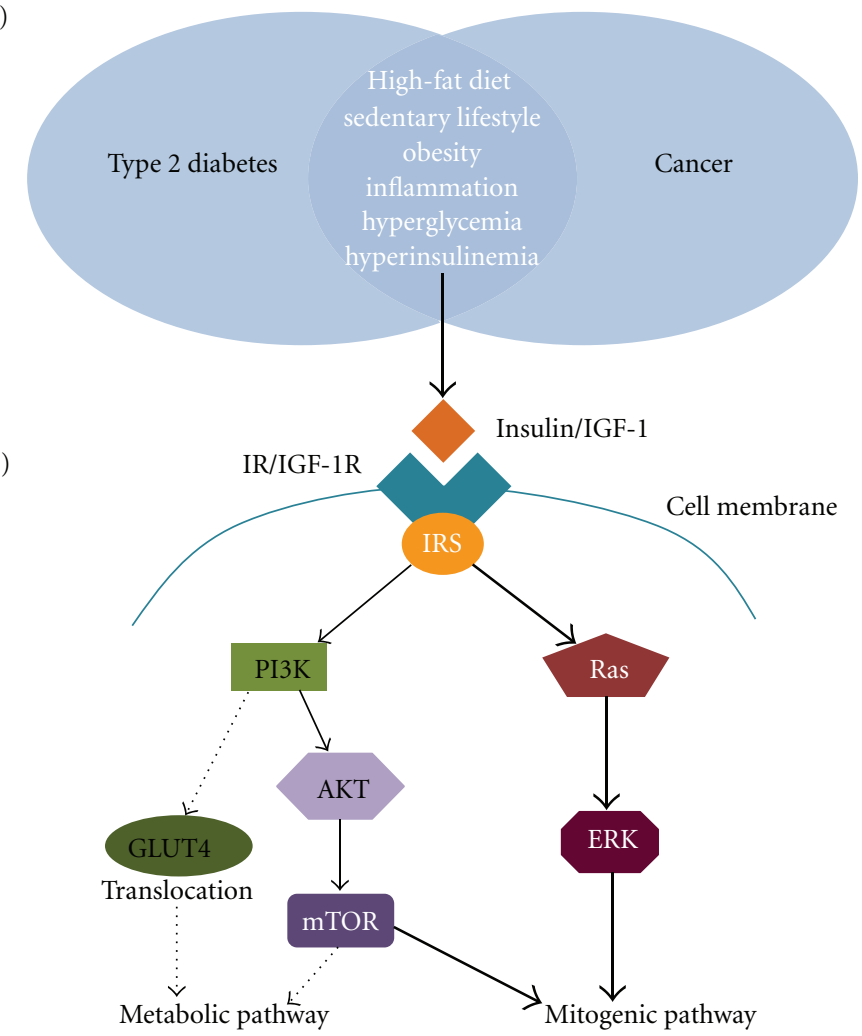

FIGURE 1: The "big picture" between DM2 and cancer. (a) The shared metabolic factors underlying both DM2 and cancer, including visceral adiposity, inflammation, hyperglycemia, and hyperinsulinemia lead to (b) increased insulin receptor substrate (IRS) stimulating the phosphorylation of Ras signaling proteins and potentially increasing tumor cell growth and proliferation. IRS-associated PI3K signaling is compromised by insulin resistant states, such as in DM2, and downstream GLUT4 translocation is disrupted. This disruption drives $\mathrm{PI} 3 \mathrm{~K}$ signaling towards AKT/mTOR. AKT and mTOR can affect both the metabolic and mitogenic pathway, but because of the signaling dysfunction, AKT and mTOR are driven towards the mitogenic pathway.

Society Cancer Prevention Study II [9] that enrolled over 1 million patients, adults with diabetes and cancer had greater mortality. In contrast, increased mortality was not found in subjects with diabetes in the National Health and Nutrition Examination Survey Mortality Followup [23].

Considering the associations between diabetes and various malignancies, can mechanisms related to diabetes development predispose to oncogenic expression? There appears to be a critical interplay between hyperglycemia, hyperinsulinemia, and adiposity, particularly central adiposity, creating a low-grade chronic inflammatory state. These elements are proposed to connect cancer development and progression to DM2 which may also influence the response to anticancer therapy. Since insulin, glycemia, adiposity, and inflammation can be modified by antidiabetes pharmacotherapy, a better understanding of their pathophysiologic links to cancer may allow us to more effectively target DM2 treatment.

Insulin, because of its known mitogenic effects, has been implicated as a key mediator in the complex mechanisms involved in carcinogenesis. Both insulin and insulin-like growth factor-1 (IGF-1) have affinity to both the insulin receptor (IR) and IGF-1 receptor (IGF-1R) because of similar structural homology. But it is important to recognize that insulin's affinity for the IR is upwards of 1000 -fold greater than for IGF-1R [24]. Both IGF-1 and IGF-1R tend to have stronger mitogenic and antiapoptotic effects, and the hyperinsulinemia that occurs in insulin-resistant individuals may enhance this effect $[1,5,18,24]$. Insulin may also indirectly promote cancer development via IGF-1. Insulin decreases IGF-binding protein-1, and possibly IGF-binding protein 2, which may increase the bioactive form of the growth factor, IGF-1 $[18,24]$ In addition, malignant cells predominantly express the A isoform of the IR (IR-A) or hybrid IR-A/IGF-1R forms, which have more mitogenic effects than the B isoform IR $[5,18,25]$. Thus, in the hyperinsulinemic individual, insulin's mitogenic properties may further oncogenic proliferation.

Furthermore, hyperinsulinemia may ultimately upregulate the insulin mitogenic pathway compared to the insulin metabolic pathway. Insulin resistant states such as obesity, metabolic syndrome, and DM2 cause impairment of downstream GLUT4 translocation by disruption of insulin receptor substrate-1 (IRS-1) associated PI3K signaling in the metabolic pathway of insulin [26]. Insulin, to a lesser extent than IGF-1, stimulates cellular growth and protein synthesis through the protein kinase $\mathrm{B}$ (PKB) system and activation 
of mTOR [27]. Abnormal IRS-1 phosphorylation from overactivation of mTOR creates a negative feedback loop that attenuates the metabolic pathway in hyperinsulinemia $[18,27]$. IRS-2 expression by insulin phosphorylation leads to increased ERK activation, a mitogen-activated protein kinase pathway (MAPK), because the mitogen pathways mediated by mTOR and Ras remain intact $[18,26,27]$. This drive towards the mitogen pathway with hyperinsulinemia leads to enhanced cell growth and survival. Figure 1(b) illustrates the potential molecular pathways, mediated by insulin, which lead to cancer. Moreover, hyperglycemia may not only promote tumorigenesis indirectly by stimulating insulin production, but also may have a direct effect, since cancer cells depend on glycolysis for energy $[6,17]$.

Central adiposity highly correlates with insulin resistance and is a key player in metabolic derangements associated with diabetes. Adipose tissue-derived cytokines, free fatty acids, and other vascular factors released from the visceral compartment have been shown to induce insulin resistance, lipid abnormalities, glucose intolerance, and low grade inflammation that collectively creates an environment ripe for cancer development and progression. In contrast, adiponectin is of particular interest for cancer prevention because of its unique metabolic properties which include the ability to decrease hepatic gluconeogenesis, to increase insulin sensitivity, and to reduce adipogenic inflammation [28-31]. Working in opposition to adiponectin are resistin, visfatin, TNF $\alpha$, IL-6, and MCP-1. These factors may increase cancer risk by perpetuating insulin resistance, hyperglycemia and inflammation $[25,28-34]$. The $30 \%$ mortality reduction related primarily to cancer and cardiovascular events following massive weight loss after bariatric surgery in morbidly obese subjects enrolled in the Swedish obesity study cohort further supports the contribution of adipocytokines in carcinogenesis [35]. However, the precise mechanisms related to lower cancer risk following surgical weight loss remains unclear.

Breast cancer is one of the more widely studied malignancies with respect to its connection to diabetes. Some studies showed an increased risk of breast malignancy in individuals with diabetes $[8-11,14-16,18]$, whereas others did not [36-39]. Although most studies were retrospective casecontrol or cohort studies [8-10, 14-18, 36-38], one of two large-scale prospective studies of more than 97,000 Japanese women showed no increase in breast cancer risk [20], whereas another with more than 116,000 women enrolled in the Nurses' Health Study, showed a mild, but significantly increased, cancer risk with a hazard ratio of 1.17 (95\% CI of 1.01-1.35) in those with diabetes [11]. Additionally, many studies demonstrate greater cancer risk in postmenopausal women with DM2 than their younger, premenopausal counterparts $[10,14,21]$. Elevations in plasma estrogen levels have been associated with postmenopausal breast cancer risk in the nondiabetes population $[1,34]$. In insulinresistant postmenopausal women, elevated serum insulin levels reduce sex-hormone-binding globulin (SHBG), resulting in increased estrogen bioavailability possibly explaining this increased risk $[1,5,34,40]$. The elevation of free estrogens is also seen in postmenopausal DM2 even after adjusting for the degree of obesity [5, 34]. Furthermore, insulin has been shown to be mitogenic in human mammary epithelial cells, but was less mitogenic compared to IGF1 [24]. In obesity, IGF-1 is an important link to breast cancer [34]. Hyperinsulinemia could stimulate IGF-1R and hybrid receptors although the clinical significance of this in breast cancer development is still unclear. It is important to remember that IGF-1 is much more mitogenic than insulin, and an insulin concentration 100 times that of IGF-1 was needed to elicit equivalent breast cancer cell growth [24]. In vitro animal models showed IGF-1 to be a significant risk factor in mammary tumor onset and development [41].

A significant risk for colorectal cancer in DM2 patients as compared to those without diabetes has been reported in a number of retrospective and prospective studies examining this relationship. Some studies show an increased risk only in men, whereas others document a risk in both genders $[18,42-47]$. As with breast cancer, the underlying factors appear to be elevated glucose, insulin and IGF-1 levels. For example, in vitro systems point to enhanced colonic tumor cell growth with elevations of both insulin and IGF-1 levels [48-51]. Decreased IGF binding proteins may also play a role in colorectal cancer development as suggested by one [51] but not other studies $[50,52,53]$.

Because the liver and pancreas are two main target organs for insulin metabolism, it is not surprising that DM2 and hepatocellular carcinoma share a link. The incidence of hepatocellular carcinoma has been reported to be higher in those with DM2 in both sexes, with a greater risk in men [1] and in those with concomitant hepatitis C infection [18, 5461]. Some studies show that DM2 increases hepatocellular cancer only in the presence of hepatitis or cirrhosis $[56,57$, $59,60]$, whereas others observe that the association exists in the absence of those characteristics $[18,54,58,61]$.

Other cancers linked to diabetes and its metabolic features include endometrial, pancreatic, kidney, and possibly gastric malignancies $[5,42,54,62]$. Older studies published in the early 1990s have indicated that individuals with diabetes $\geq 5$ years appear to have an increased risk of pancreatic cancer $[63,64]$. More recent studies show that pancreatic cancer risk occurs within the first decade of the diagnosis of DM2, and some argue that the highest risk is within 2-3 years of DM2 onset $[65,66]$. Controversy regarding pancreatic cancer has evolved from the "chicken or egg" issue: does pancreatic cancer cause diabetes or does this malignancy result from diabetes? Some investigators would argue that diabetes is a result of pre-existing pancreatic cancer causing destruction of $B$-cells via tumor infiltration [65]. The tumor burden would have to be extensive for a physical loss of islet cells to cause DM2. Newer hypotheses suggests that DM2 results more from peripheral insulin resistance and disruption of amylin secretion in $\beta$-cells $[67,68]$ from a paraneoplastic effect of the tumor cells, rather than a physical destruction of $\beta$-cells. One epidemiologic case-control study by Chari et al. suggest that pancreatic cancer may cause DM2 through alteration of glucose metabolism in the liver and skeletal muscle, thereby inducing glucose intolerance [66]. Moreover, elevated glucose levels are associated with increased pancreatic cancer mortality [63]. Regardless of the 
exact nature of the association, it is clear that a relationship exists between DM2 and pancreatic cancer.

Interestingly, the presence of Helicobacter pylori may increase gastric cancer risk [69-71] in diabetes, possibly mediated through an insulin resistance/hyperinsulinemia pathway [70]. Increase in gastrin levels, decrease in somatostatin levels, and increase in neutrophilic and monocytic infiltration of the gastric mucosa in patients with $H$. pylori infection may lead to insulin resistance [70]. Eradication of $H$. pylori may mitigate the gastric cancer risk [72]. However, the prevalence findings of $H$. pylori in DM2 patients has been variable, and we do not yet clearly understand the clinical implications in this population.

There are also studies arguing against an association between diabetes and cancer, specifically for ovarian, lung, and prostate malignancies $[5,42,73,74]$. In prostate cancer, DM2 appears to have a protective effect, and like pancreatic cancer, there is a temporal relationship, with the protective effect occurring later in DM2 $[62,74]$. Circulating insulin levels are inversely correlated with dihydrotestosterone, testosterone, and SHBG. Thus, it has been proposed that the lower testosterone levels that occur in DM2 may be a mechanism of decreased prostate cancer risk [74]. However, elevated circulating testosterone levels are not a consistent finding associated with prostate cancer $[5,9,62]$. Another suggested mechanism that may explain the time-associated inverse relationship is the change in insulin levels as DM2 progresses. IGF-1 levels have been associated with increased prostate cancer risk. Insulin downregulates IGF binding protein 1, and as insulin levels decrease over time through reduction in $\beta$-cell mass with DM2 disease progression, there is less downregulation of IGF-binding protein 1. Since IGF binding protein 1 controls the amount of IGF-1 free levels, less circulating insulin may indirectly mitigate prostate cancer risk $[9,62,74,75]$.

The studies examining the relationship between DM2 and hematopoietic malignancies appear to show a positive relationship between diabetes and hematopoietic cancers [6, $37]$, but this finding is not consistent in all studies $[42,76]$. Major limitations of these studies include self-reported data regarding the diagnosis of diabetes, which makes it difficult to clearly ascertain the exact links between diabetes and hematopoietic cancers. Oxidative stress and cellular damage related to hyperglycemia may be involved in the association between the two $[22,77,78]$. One prospective cohort study found a positive association between postload plasma glucose levels in non-diabetes patients and non-Hodgkin's lymphoma in men and a 3-fold increased mortality risk from multiple myeloma in women at the highest level of post-load plasma glucose levels [78]. Clearly, further studies are needed in this arena.

\subsection{Antidiabetes Therapy and Cancer Risk}

1.3.1. Insulin Analogues and Cancer. Insulin is a known mitogen that stimulates the MAPK pathway leading to increases in growth factors. In addition, insulin down-regulates IGF binding proteins which may contribute to sex-steroid dependent cancers in diabetes, particularly postmenopausal breast and endometrial malignancies. In vitro studies have shown that high insulin levels can affect angiogenesis and potentially propagate tumor progression by stimulating the mitogen pathway via both insulin and IGF receptors $[92,93]$. A number of studies have examined the effect of exogenous insulin usage with cancer. These studies are summarized in Tables 1 (b) and 1(c). An initial concern was raised by the provocative report of a retrospective German study suggesting an increased cancer risk with glargine use [87]. Since then, most large-scale studies have focused on glargine although other insulin analogues have been studied as well. The results from retrospective studies are conflicting, with some studies showing an increased risk of malignancy [22, 82, 85-87, 94], whereas others $[82,83,88,88,89,89,90,90,91,91]$ did not.

In vitro studies may help explain the basis of the concern regarding insulin analogues, particularly glargine. Weinstein et al. studied the comparative mitogenic effect at supraphysiologic doses of regular insulin and insulin analogues glargine, detemir, lispro, and aspart to IGF-1 in cancerderived cell lines from colon (HCT116), prostate (PC3), and breast (MCF-7) [95]. The insulin analogues glargine, detemir and lispro stimulated proliferation with a dose-dependent effect of all three cell lines but less than IGF-1. Regular and aspart insulin had the lowest mitogenic effect compared to the other insulin analogues and IGF-1 [95]. Furthermore, studies [95-97] indicate that glargine induced MCF-7 breast cancer cell proliferation to a significant level compared to the MCF-10 cells, but the stimulation was less compared to IGF-1. This discrepancy in responses between the two breast cancer cell lines is attributed to the differences in relative cellular IGF-1R and IR expression [24]. However, one study by Liefvendahl et al. found that glargine had little to no increased mitogenic effect in malignant cell lines for breast cancer (MCF-7 and SKBR-3) or osteosarcoma (SaOS-2) compared to human insulin [93], The caveat in this controversy may relate to a dose-time exposure to insulin treatment, particularly with glargine; that is, cumulative insulin intake over time may potentially increase the cancer risk and mortality [98]. Because of all the controversy, the FDA has concluded that glargine is safe, but it is awaiting longer-term prospective studies regarding malignancy potential.

1.4. Oral Hypoglycemic Agents and Cancer. Agents which treat or prevent DM2 might be expected to influence risk of cancer favorably. Current oral agents that treated DM2 fall into two broad general categories: insulin providing (secretagogues, metiglinides, and incretin analogs) and insulinsensitizing (metformin and thiazolidinediones). The insulin sensitizers, metformin, and thiazolidinediones (TZDs) are promising cancer therapies, because they not only lower glucose, insulin and fatty acid levels, but also may have unique anticarcinogenic properties that will be discussed below.

1.4.1. Insulin Sensitizers (Biguanides and Thiazolidinediones). Metformin is generally used as a first-line agent for DM2 treatment; it decreases hepatic glucose output and increases glucose disposal in muscle, thereby reducing levels of circulating serum glucose and insulin levels. Epidemiological studies in diabetic patients have shown that metformin may 
TABLE 1: Cancer risk with oral agents and insulin therapy.

(a) Population studies of oral antidiabetic medications and cancer risk

\begin{tabular}{|c|c|c|c|c|}
\hline Study & $\begin{array}{l}\text { Publish year country } \\
\text { (study Yrs) }\end{array}$ & \multicolumn{2}{|c|}{ Increased risk (OR with 95\% CI) } & Cancer type(s) \\
\hline $\begin{array}{l}\text { Evans et al. [79] } \\
\text { case-control } \\
\text { hospitalized patients }\end{array}$ & $\begin{array}{l}2005 \text { Scotland } \\
(1993-2001)\end{array}$ & \multicolumn{2}{|l|}{$\begin{array}{l}\text { No } \\
\text { (i) Metformin (OR 0.77) }\end{array}$} & $\begin{array}{l}\text { None specified (All } \\
\text { incidence of cancers) }\end{array}$ \\
\hline $\begin{array}{l}\text { Bowker et al. [80] } \\
\text { retrospective }\end{array}$ & $\begin{array}{l}2006 \text { Canada } \\
(1991-1996)\end{array}$ & & $\begin{array}{l}\text { Yes } \\
\text { (i) SFU compared to } \\
\text { metformin (HR 1.3, } \\
P=.012 \text { ) } \\
\text { (ii) Insulin (HR 1.9, } \\
P=.0001)\end{array}$ & $\begin{array}{l}\text { None specified (Looked } \\
\text { specifically at } \\
\text { cancer-related mortality } \\
\text { and not cancer type.) }\end{array}$ \\
\hline $\begin{array}{l}\text { Monami et al. [81] } \\
\text { case control }\end{array}$ & $\begin{array}{l}2009 \text { Italy } \\
(1998-2004)\end{array}$ & $\begin{array}{l}\text { After >36 months of use: } \\
\text { No } \\
\text { (i) Acarbose (OR 0.77) } \\
\text { (ii) Glicazide (OR 0.40) } \\
\text { (iii) Glitazones (OR } \\
\text { 1.05) } \\
\text { (iv) Insulin (OR 0.91) } \\
\text { (v) Metformin (OR } \\
0.28 \text { ) } \\
\text { (vi) Other SFU (OR } \\
\text { 1.05) } \\
\text { (vii) Repaglinide (OR } \\
0.87 \text { ) } \\
\end{array}$ & $\begin{array}{l}\text { After }>36 \text { months of use: } \\
\text { Yes } \\
\text { (i) Glibenclamide (OR } \\
2.62, P=.009)\end{array}$ & $\begin{array}{l}\text { GI breast } \\
\text { genital tract } \\
\text { (male/female) } \\
\text { pancreas } \\
\text { lung }\end{array}$ \\
\hline $\begin{array}{l}\text { Li et al. [64] case } \\
\text { control hospitalized } \\
\text { patients }\end{array}$ & $\begin{array}{l}2009 \text { United States } \\
(2004-2008)\end{array}$ & $\begin{array}{l}\text { No } \\
\text { (i) Metformin (OR 0.38) }\end{array}$ & $\begin{array}{l}\text { Yes } \\
\text { (i) Insulin (OR 4.99) } \\
\text { (ii) Insulin } \\
\text { secretagogues (OR 2.52) } \\
\text { (iii) TZD's (OR 1.55) }\end{array}$ & $\begin{array}{l}\text { Pancreas } \\
\text { (adenocarcinoma) }\end{array}$ \\
\hline $\begin{array}{l}\text { Mannucci et al. [82] } \\
\text { case control }\end{array}$ & $\begin{array}{l}2010 \text { Italy } \\
(1998-2007)\end{array}$ & $\begin{array}{l}\text { No } \\
\text { (i) Other insulin: lispro, } \\
\text { aspart, and human } \\
\text { insulin } \\
\text { (ii) Metformin }\end{array}$ & $\begin{array}{l}\text { Yes } \\
\text { (i) } \geq 0.3 \mathrm{IU} / \mathrm{kg} / \mathrm{d} \text { of } \\
\text { glargine }\end{array}$ & $\begin{array}{l}\text { GI } \\
\text { hepatic } \\
\text { pancreatic } \\
\text { lung } \\
\text { leukemia/lymphoma } \\
\text { breast } \\
\text { urogenital } \\
\text { prostate } \\
20 \text { "other cancers" }\end{array}$ \\
\hline
\end{tabular}

(b) Meta-analyses of insulin and cancer

\begin{tabular}{|c|c|c|c|c|c|c|}
\hline Study & $\begin{array}{l}\text { Publish Year } \\
\text { country }\end{array}$ & $\begin{array}{l}\text { Total number } \\
\text { of studies }\end{array}$ & Total $(n)$ & $\begin{array}{l}\text { Insulin } \\
\text { analyzed }\end{array}$ & \multicolumn{2}{|c|}{ Increased risk? } \\
\hline $\begin{array}{l}\text { Dejgaard et al. [ } 83] \\
\text { Meta-analysis of } \\
\text { randomized controlled } \\
\text { Novo Nordisk trials } \\
\text { Type I and Type II }\end{array}$ & $\begin{array}{c}2009 \\
\text { Denmark }\end{array}$ & 21 & 8693 & $\begin{array}{c}\text { Detemir } \\
\text { NPH glargine }\end{array}$ & $\begin{array}{l}\text { No } \\
\text { (i) Glargine and } \\
\text { detemir had } \\
\text { similar risk }\end{array}$ & $\begin{array}{l}\text { Yes } \\
\text { (i) NPH had } \\
\text { more risk than } \\
\text { detemir }\end{array}$ \\
\hline $\begin{array}{l}\text { Home et al. [84] } \\
\text { Meta-analysis of } \\
\text { randomized controlled } \\
\text { Sanofi Aventis trials } \\
\text { Type I and Type II }\end{array}$ & $\begin{array}{l}2009 \text { United } \\
\text { Kingdom }\end{array}$ & 31 & 10,880 & Glargine & No & \\
\hline
\end{tabular}


(c) Population studies of insulin and cancer risk

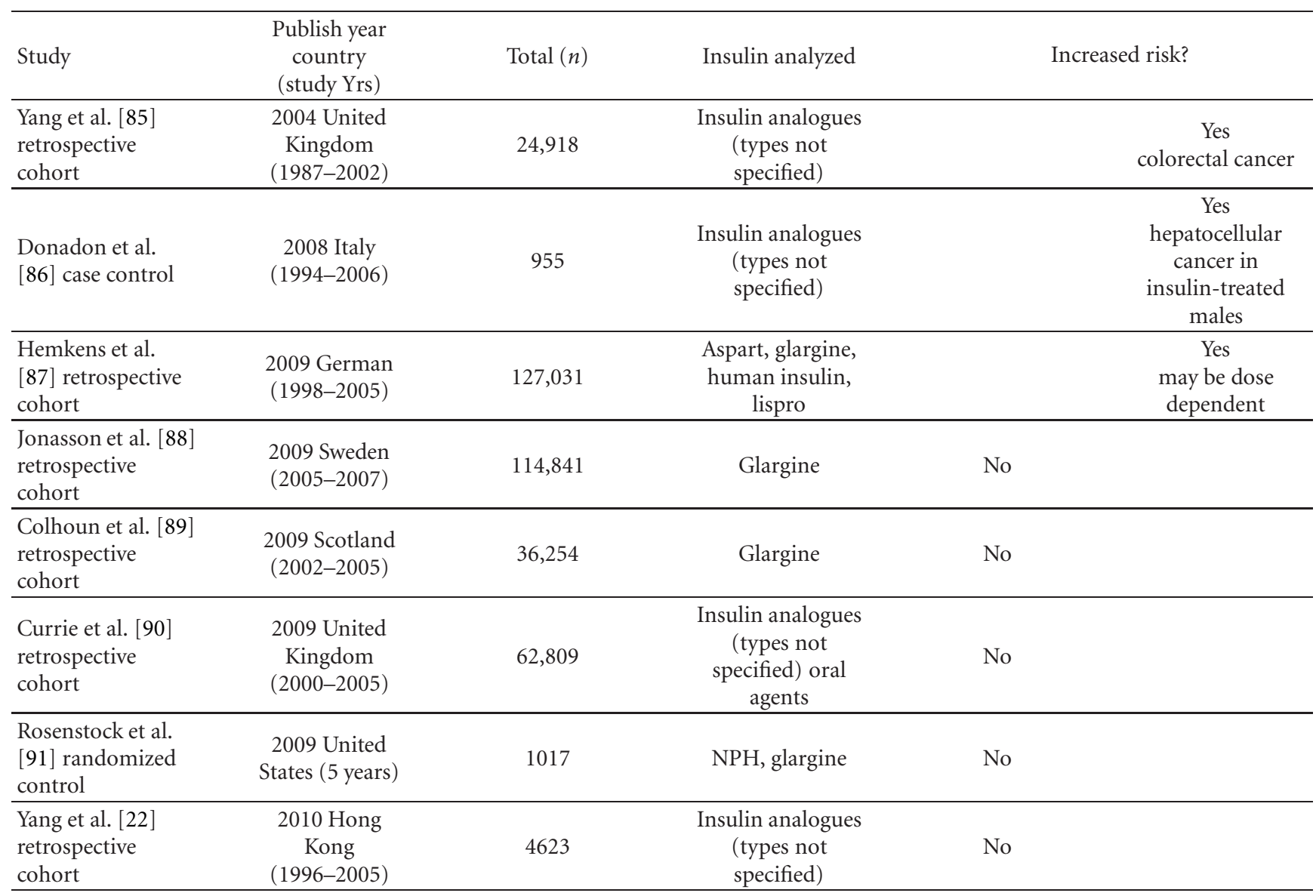

be neutral [99] or protective of cancer risk [64, 80, 81, 90, $100,101]$. Table 1(a) displays data from several population studies examining oral anti-diabetes agents and cancer risk. A meta-analysis of diabetes studies with 4,042 cancer events and 529 cancer deaths demonstrated a 31\% reduction in relative risk with metformin versus other antidiabetic drugs [102]. In vitro cell culture studies as well as animal studies have clearly demonstrated antitumor properties of metformin [103-108]. Mice mammary tumor growth was reduced by metformin, indicating a potential chemotherapeutic role in human breast cancer therapy [103]. The mechanisms for the anti-tumor effects of metformin include an inhibition of cell proliferation, decrease cancer proliferation, with partial cell-cycle arrest in oncogenic cell lines with the activation of $5^{\prime}$ adenosine monophosphate-activated protein (AMP) and AMP-kinase (AMPK) [5]. AMPK is an essential mediator of the tumor suppressor LKB1. Because of its properties, AMPK could be used to suppress cancer cells containing loss-of-function LKB1 mutations, active B-Raf mutations, or in cancers associated with metabolic syndrome. The activation of AMPK reprograms cellular metabolism by acting on mTORC1, p53, fatty acid synthase, and other molecules involved with regulating cell growth and metabolism [106].

Thiazolidinediones, or TZDs as they are more commonly known (i.e., rosiglitazone and pioglitazone), bind to peroxisome proliferator-activated receptor (PPAR) gamma $(\gamma)$ receptor molecules inside the cell nucleus which, when activated, result in transcription of a variety of genes. PPAR $\gamma$ is an adipocyte transcription factor, stimulating differentiation of adipocytes as well as inhibiting inflammatory cytokine production [109]. This class of drugs reduces insulin levels by enhancing insulin action. PPAR $\gamma$ activation results in reduced free fatty acids and eicosanoids and inhibition of VEGF-induced angiogenesis, amongst other actions [110]. Like metformin, TZDs inhibit cancer cell growth, potentiation, and proliferation, inducing apoptosis, at the in vitro level $[5,34]$. Conversely, there are studies in rodents showing increased tumorigenesis by PPAR $\gamma$ agonists. Epidemiologic studies have shown inconclusive results with a recent meta-analysis [111] showing no effect on malignancy risk. Overall, studies examining TZDs are limited because of the short-term exposure and limited cases of cancer at specific sites. A phase 1 trial using thiazolidinediones in combination with chemotherapy for refractory cancers was negative, but large-scale controlled studies are warranted $[5,112]$.

1.4.2. Secretagogues (Sulfonylureas and Meglitinides). Secretagogues stimulate insulin production by binding to specific cell receptors that result in depolarization of pancreatic beta cells [81]. Sulfonylurea (SFU) use, like insulin, has 
been implicated in cancer risk. Glitinides are less commonly used, and their association with cancer is unknown. A few observational studies have associated SFU use with higher cancer risk. However, the limitations of these studies relate to the lack of power given the small numbers of cancer events [80]. In addition, most studies have not addressed differences between the various SFU agents with one small study suggesting variable effects [81]. The effect of oral diabetic agents on incidence of malignancy was extracted from two randomized controlled trials, ADOPT (A Diabetes Outcome Progression Trial) and RECORD (Rosiglitazone Evaluated for Cardiovascular Outcomes and Regulation of Glycaemia in Diabetes). Despite a total study exposure of 39,000 person/years over a 4 - to 6 -year duration, neither trial demonstrated an advantage of metformin over rosiglitzone or SFUs on cancer rates. The hazard ratio for metformin versus rosiglitazone was close to 1.0 in both studies [99]. However, the data regarding SFUs is less clear with a nonstatistically significant reduction of 22\% (95\% CI $0.53-$ $1.14)$ in ADOPT for metformin versus SFUs and 25\% (95\% CI 0.85-1.18) in RECORD for rosiglitazone versus SFUs [99].

1.4.3. Alpha Glucosidase Inhibitors (Acarbose). Acarbose, an $\alpha$-glucosidase inhibitor, curbs postprandial blood glucose excursions by inhibiting the enzymatic degradation of carbohydrates in the small intestines brush border. Although cancer risk information regarding $\alpha$-glucosidase inhibitors is limited, one study suggests that acarbose may augment butyrate, a colonocyte energy source with anticolon cancer effects. This particular study showed promising results of acarbose use to enhance fecal butyrate concentrations, which may favorably affect colonic neoplasia [113].

1.4.4. DPP-IV Inhibitors and GLP-1 Agonists. Dipeptidyl peptidase-IV (DPP-IV) inhibitors, as well as glucagon-like peptide-1 (GLP-1) agonists, are relatively new medications in the arsenal of treatment of DM2. Sitagliptin, one of two available DPP-IV inhibitors in the US, initially made its debut in 2006 followed by the release of saxagliptin in 2009. The noninsulin injectable GLP-1 agonists, exenatide and liraglutide, were first introduced in the US in 2005, with a onceweekly option on the horizon. These therapies are effective in preserving $ß$-cell mass by inhibiting apoptosis as well as improving islet cell function $[114,115]$. GLP-1 is an incretin hormone that stimulates up to $70 \%$ of glucose-dependent insulin secretion after an oral stimulus, and in non-DM2 patients, there is a quick first-phase insulin surge followed by a longer second-phase response. DM2 patients have approximately $80 \%$ decreased $B$-cell function as a result of increased cell death from the oxidative stress of persistent hyperglycemia [114]. Subsequently, the first phase of insulin is lost in DM2. GLP-1 receptor agonists and the DPP-IV inhibitors, which inhibit the enzymatic breakdown of endogenous GLP1 , can restore $ß$-cell sensitivity to glucose, increase $ß$-cell mass, and improve overall islet cell function $[114,115]$.

Their relatively short-term use clinically does not permit meaningful data on malignancy potential or risks. Thus, only in vitro and animal studies may be used to address a potential risk. DPP-IV has a complex role in relationship to cancer and may influence all stages of cancer from apoptosis, migration, invasion, and metastasis to even chemotherapy sensitivity [116]. Sitagliptin showed increased pancreatic ductal hyperplasia in a small rodent model study [5]. Increased ductal cell turnover and ductal metaplasia may predispose to pancreatic cancer risk although one shortterm study involving human pancreatic cancer cell lines did not result in cell proliferation with activation of GLP-1R signaling. This lack of cell proliferation even after activation of functional GLP-1R may be a result of GLP-1R expression in the transduction pathway activation in pancreatic cancer cells [117]. Of the two GLP-1 agonists, liraglutide was associated with thyroid C-cell hyperplasia/tumor growth in rodents mediated by GLP-1 receptor agonist stimulating calcitonin gene expression $[5,118]$. However, humans have shown low GLP-1 receptor expression in thyroid C-cells, which may be an indication of species-specific differences in GLP-1 receptor expression [118].

\section{Conclusions}

With the current diabetes pandemic running in parallel to the one for obesity, there is a growing need to identify pathophysiologic links underlying cancer risk and mortality in this high risk population. The diabetes/metabolic syndrome certainly appears to increase the risk of certain malignancies, including breast, endometrial, colorectal, hepatocellular, and possibly others. Since DM2 may be preventable and certainly treatable with lifestyle modification and pharmacotherapy, cancer risk may also be lowered by these strategies. Certain anti-diabetes therapies (e.g., biguanides) may become the adjuvant chemotherapy of the future. However, large-scale controlled trials are warranted. The role of exogenous insulin administration for cancer risk in diabetes remains controversial; further clinical trials are needed.

\section{Abbreviations}

$\begin{array}{ll}\text { DM2: } & \text { Type } 2 \text { diabetes mellitus } \\ \text { BMI: } & \text { Body mass index } \\ \text { IGF: } & \text { Insulin-like growth factor } \\ \text { IR: } & \text { Insulin receptor } \\ \text { Ras: } & \text { Rat sarcoma protein } \\ \text { PKB: } & \text { Protein kinase B } \\ \text { mTOR: } & \text { mammalian target of rapamycin } \\ \text { TNF } \alpha: & \text { Tissue necrosis factor } \alpha \\ \text { PI3K: } & \text { Phosphatidylinositol-3 kinase } \\ \text { GLUT4: } & \text { Glucose transporter type } 4 \\ \text { MAPK: } & \text { Mitogen-activated protein kinase } \\ \text { IL-6: } & \text { Interleukin-6 } \\ \text { Akt: } & \text { Serine/threonine-specific protein kinase } \\ \text { MCP-1: } & \text { Monocyte chemoattractant protein-1 } \\ \text { VEGF: } & \text { Vascular endothelial growth factor } \\ \text { AMP: } & 5 \text { ' adenosine monophosphate activated } \\ & \text { protein } \\ \text { IRS: } & \text { Insulin receptor substrate } \\ \text { SFU: } & \text { Sulfonylurea } \\ \text { TZD: } & \text { Thiazolidinedione } \\ \text { GLP-1: } & \text { Glucagon-like peptide-1. }\end{array}$




\section{Disclosure}

The authors have nothing to disclose.

\section{Acknowledgment}

The authors are grateful for the thoughtful review and editorial assistance of this paper by Dr. Charles Faiman, M.D. S. R. Kashyap is supported by National Institutes of Health, RO1 DK089547-01 NIDDK/NIH and grants from the American Diabetes Association.

\section{References}

[1] A. Czyzyk and Z. X. Szczepanik, "Diabetes mellitus and cancer," European Journal of Internal Medicine, vol. 11, no. 5, pp. 245-252, 2000.

[2] "National Information Diabetes Clearinghouse. National Diabetes Statistics," 2007, http://diabetes.niddk.nih.gov/dm/ pubs/statistics/.

[3] American Cancer Society, "Cancer Facts and Figures," 2009, http://www.cancer.org/Research/CancerFactsFigures/cancerfacts-figures-2009.

[4] American Diabetes Association, http://www.diabetes.org/ diabetes-basics/diabetes-statistics/.

[5] E. Giovannucci, D. M. Harlan, M. C. Archer et al., "Diabetes and cancer: a consensus report," CA Cancer Journal for Clinicians, vol. 60, no. 4, pp. 207-221, 2010.

[6] W. Levine, A. R. Dyer, R. B. Shekelle, J. A. Schoenberger, and J. Stamler, "Post-load plasma glucose and cancer mortality in middle-aged men and women. 12-year follow-up findings of the Chicago Heart Association Detection Project in Industry," American journal of epidemiology, vol. 131, no. 2, pp. 254-262, 1990.

[7] L. S. A. Augustin, S. Gallus, S. Franceschi et al., "Glycemic index and load and risk of upper aero-digestive tract neoplasms (Italy)," Cancer Causes and Control, vol. 14, no. 7, pp. 657-662, 2003.

[8] J. A. Baron, E. Weiderpass, P. A. Newcomb et al., "Metabolic disorders and breast cancer risk (United States)," Cancer Causes and Control, vol. 12, no. 10, pp. 875-880, 2001.

[9] S. S. Coughlin, E. E. Calle, L. R. Teras, J. Petrelli, and M. J. Thun, "Diabetes mellitus as a predictor of cancer mortality in a large cohort of US adults," American Journal of Epidemiology, vol. 159, no. 12, pp. 1160-1167, 2004.

[10] L. L. Lipscombe, P. J. Goodwin, B. Zinman, J. R. McLaughlin, and J. E. Hux, "Diabetes mellitus and breast cancer: a retrospective population-based cohort study," Breast Cancer Research and Treatment, vol. 98, no. 3, pp. 349-356, 2006.

[11] K. B. Michels, C. G. Solomon, F. B. Hu et al., "Type 2 diabetes and subsequent incidence of breast cancer in the nurses' health study," Diabetes Care, vol. 26, no. 6, pp. 1752-1758, 2003.

[12] E. Friberg, N. Orsini, C. S. Mantzoros, and A. Wolk, "Diabetes mellitus and risk of endometrial cancer: a metaanalysis," Diabetologia, vol. 50, no. 7, pp. 1365-1374, 2007.

[13] K. E. Anderson, E. Anderson, P. J. Mink et al., "Diabetes and endometrial cancer in the Iowa Women's Health Study," Cancer Epidemiology Biomarkers and Prevention, vol. 10, no. 6, pp. 611-616, 2001.
[14] R. Talamini, S. Franceschi, A. Favero, E. Negri, F. Parazzini, and C. La Vecchia, "Selected medical conditions and risk of breast cancer," British Journal of Cancer, vol. 75, no. 11, pp. 1699-1703, 1997.

[15] E. Weiderpass, G. Gridley, I. Persson, O. Nyrén, A. Ekbom, and H. O. Adami, "Risk of endometrial and breast cancer in patients with diabetes mellitus," International Journal of Cancer, vol. 71, no. 3, pp. 360-363, 1997.

[16] L. Wideroff, G. Gridley, L. Mellemkjaer et al., "Cancer incidence in a population-based cohort of patients hospitalized with diabetes mellitus in denmark," Journal of the National Cancer Institute, vol. 89, no. 18, pp. 1360-1365, 1997.

[17] J. Yun, C. Rago, I. Cheong et al., "Glucose deprivation contributes to the development of KRAS pathway mutations in tumor cells," Science, vol. 325, no. 5947, pp. 1555-1559, 2009.

[18] P. Vigneri, F. Frasca, L. Sciacca, G. Pandini, and R. Vigneri, "Diabetes and cancer," Endocrine-Related Cancer, vol. 16, no. 4, pp. 1103-1123, 2009.

[19] HA. J. Sun, H. Ohrr, W. S. Jae, E. Y. Ji, M. Ji, and J. M. Samet, "Fasting serum glucose level and cancer risk in Korean men and women," Journal of the American Medical Association, vol. 293, no. 2, pp. 194-202, 2005.

[20] M. Inoue, M. Iwasaki, T. Otani, S. Sasazuki, M. Noda, and S. Tsugane, "Diabetes mellitus and the risk of cancer: results from a large-scale population-based cohort study in Japan," Archives of Internal Medicine, vol. 166, no. 17, pp. 1871-1877, 2006.

[21] B. B. Barone, H. C. Yeh, C. F. Snyder et al., "Long-term all-cause mortality in cancer patients with preexisting diabetes mellitus: a systematic review and meta-analysis," Journal of the American Medical Association, vol. 300, no. 23, pp. 2754-2764, 2008.

[22] X. Yang, G. T. C. Ko, W. Y. So et al., "Associations of hyperglycemia and insulin usage with the risk of cancer in type 2 diabetes: the Hong Kong diabetes registry," Diabetes, vol. 59, no. 5, pp. 1254-1260, 2010.

[23] K. Steenland, S. Nowlin, and S. Palu, "Cancer incidence in the national health and nutrition survey I follow-up data: diabetes, cholesterol, pulse, and physical activity," Cancer Epidemiology Biomarkers and Prevention, vol. 4, no. 8, pp. 807-811, 1995.

[24] T. P. Ciaraldi and T. Sasaoka, "Review on the in vitro interaction of insulin glargine with the insulin/insulin-like growth factor system: potential implications for metabolic and mitogenic activities," Hormone and Metabolic Research, vol. 43, no. 1, pp. 1-10, 2011.

[25] A. Belfiore, F. Frasca, G. Pandini, L. Sciacca, and R. Vigneri, "Insulin receptor isoforms and insulin receptor/insulin-like growth factor receptor hybrids in physiology and disease," Endocrine Reviews, vol. 30, no. 6, pp. 586-623, 2009.

[26] K. Cusi, K. Maezono, A. Osman et al., "Insulin resistance differentially affects the PI 3-kinase- and MAP kinasemediated signaling in human muscle," Journal of Clinical Investigation, vol. 105, no. 3, pp. 311-320, 2000.

[27] S. G. Dann, A. Selvaraj, and G. Thomas, "mTOR Complex1S6K1 signaling: at the crossroads of obesity, diabetes and cancer," Trends in Molecular Medicine, vol. 13, no. 6, pp. 252-259, 2007.

[28] R. S. Ahima, "Metabolic actions of adipocyte hormones: focus on adiponectin," Obesity, vol. 14, supplement 1, pp. 9S-15S, 2006.

[29] R. S. Ahima, "Central actions of adipocyte hormones," Trends in Endocrinology and Metabolism, vol. 16, no. 7, pp. 307-313, 2005. 
[30] P. J. Havel, "Update on adipocyte hormones: regulation of energy balance and carbohydrate/lipid metabolism," Diabetes, vol. 53, no. 1, pp. S143-S151, 2004.

[31] M. B. Jackson and R. S. Ahima, "Neuroendocrine and metabolic effects of adipocyte-derived hormones," Clinical Science, vol. 110, no. 2, pp. 143-152, 2006.

[32] K. Cusi, "The role of adipose tissue and lipotoxicity in the pathogenesis of type 2 diabetes," Current Diabetes Reports, vol. 10, pp. 306-315, 2010.

[33] C. M. Steppan, S. T. Bailey, S. Bhat et al., "The hormone resistin links obesity to diabetes," Nature, vol. 409, no. 6818, pp. 307-312, 2001.

[34] I. Wolf, S. Sadetzki, R. Catane, A. Karasik, and B. Kaufman, "Diabetes mellitus and breast cancer," Lancet Oncology, vol. 6, no. 2, pp. 103-111, 2005.

[35] L. Sjöström, "Bariatric surgery and reduction in morbidity and mortality: experiences from the SOS study," International Journal of Obesity, vol. 32, supplement 7, pp. S93-S97, 2008.

[36] H. A. Weiss, L. A. Brinton, N. A. Potischman et al., "Breast cancer risk in young women and history of selected medical conditions," International Journal of Epidemiology, vol. 28, no. 5, pp. 816-823, 1999.

[37] H. Hjalgrim, M. Frisch, A. Ekbom, K. O. Kyvik, M. Melbye, and A. Green, "Cancer and diabetes-a follow-up study of two population-based cohorts of diabetic patients," Journal of Internal Medicine, vol. 241, no. 6, pp. 471-475, 1997.

[38] C. La Vecchia, E. Negri, S. Franceschi, B. D’Avanzo, and P. Boyle, "A case-control study of diabetes mellitus and cancer risk," British Journal of Cancer, vol. 70, no. 5, pp. 950-953, 1994.

[39] P. J. Mink, E. Shahar, W. D. Rosamond, A. J. Alberg, and A. R. Folsom, "Serum insulin and glucose levels and breast cancer incidence: the atherosclerosis risk in communities study," American Journal of Epidemiology, vol. 156, no. 4, pp. 349-352, 2002.

[40] A. G. Renehan, M. Zwahlen, C. Minder, S. T. O’Dwyer, S. M. Shalet, and M. Egger, "Insulin-like growth factor (IGF)-I, IGF binding protein-3, and cancer risk: systematic review and meta-regression analysis," Lancet, vol. 363, no. 9418, pp. 1346-1353, 2004.

[41] Y. Wu, K. Cui, K. Miyoshi et al., "Reduced circulating insulinlike growth factor I levels delay the onset of chemically and genetically induced mammary tumors," Cancer Research, vol. 63, no. 15, pp. 4384-4388, 2003.

[42] H. O. Adami, J. McLaughlin, A. Ekbom et al., "Cancer risk in patients with diabetes mellitus," Cancer Causes and Control, vol. 2, no. 5, pp. 307-314, 1991.

[43] F. B. Hu, J. E. Manson, S. Liu et al., "Prospective study of adult onset diabetes mellitus (type 2) and risk of colorectal cancer in women," Journal of the National Cancer Institute, vol. 91, no. 6, pp. 542-547, 1999.

[44] C. La Vecchia, E. Negri, A. Decarli, and S. Franceschi, "Diabetes mellitus and colorectal cancer risk," Cancer Epidemiology Biomarkers and Prevention, vol. 6, no. 12, pp. 1007-1010, 1997.

[45] S. C. Larsson, E. Giovannucci, and A. Wolk, "Diabetes and colorectal cancer incidence in the cohort of Swedish men," Diabetes Care, vol. 28, no. 7, pp. 1805-1807, 2005.

[46] S. C. Larsson, N. Orsini, and A. Wolk, "Diabetes mellitus and risk of colorectal cancer: a meta-analysis," Journal of the National Cancer Institute, vol. 97, no. 22, pp. 1679-1687, 2005.
[47] A. Seow, J. M. Yuan, W. P. Koh, H. P. Lee, and M. C. Yu, "Diabetes mellitus and risk of colorectal cancer in the Singapore Chinese health study," Journal of the National Cancer Institute, vol. 98, no. 2, pp. 135-138, 2006.

[48] S. H. Saydah, C. M. Loria, M. S. Eberhardt, and F. L. Brancati, "Abnormal glucose tolerance and the risk of cancer death in the United States," American Journal of Epidemiology, vol. 157, no. 12, pp. 1092-1100, 2003.

[49] T. I. L. Nilsen and L. J. Vatten, "Prospective study of colorectal cancer risk and physical activity, diabetes, blood glucose and BMI: exploring the hyperinsulinaemia hypothesis," British Journal of Cancer, vol. 84, no. 3, pp. 417-422, 2001.

[50] T. O. Keku, P. K. Lund, J. Galanko, J. G. Simmons, J. T. Woosley, and R. S. Sandler, "Insulin resistance, apoptosis, and colorectal adenoma risk," Cancer Epidemiology Biomarkers and Prevention, vol. 14, no. 9, pp. 2076-2081, 2005.

[51] R. Kaaks, P. Toniolo, A. Akhmedkhanov et al., "Serum C-peptide, insulin-like growth factor (IGF)-I, IGF-binding proteins, and colorectal cancer risk in women," Journal of the National Cancer Institute, vol. 92, no. 19, pp. 1592-1600, 2000.

[52] R. Palmqvist, P. Stattin, S. Rinaldi et al., "Plasma insulin, IGF-binding proteins-1 and -2 and risk of colorectal cancer: a prospective study in Northern Sweden," International Journal of Cancer, vol. 107, no. 1, pp. 89-93, 2003.

[53] S. H. Saydah, E. A. Platz, N. Rifai, M. N. Pollak, F. L. Brancati, and K. J. Helzlsouer, "Association of markers of insulin and glucose control with subsequent colorectal cancer risk," Cancer Epidemiology Biomarkers and Prevention, vol. 12, no. 5, pp. 412-418, 2003.

[54] A. B. De Gonzalez, E. Y. Ji, S. Y. Lee, A. P. Klein, and HA. J. Sun, "Pancreatic cancer and factors associated with the insulin resistance syndrome in the Korean cancer prevention study," Cancer Epidemiology Biomarkers and Prevention, vol. 17, no. 2, pp. 359-364, 2008.

[55] J. A. Davila, R. O. Morgan, Y. Shaib, K. A. McGlynn, and H. B. El-Serag, "Diabetes increases the risk of hepatocellular carcinoma in the United States: a population based case control study," Gut, vol. 54, no. 4, pp. 533-539, 2005.

[56] H. B. El-Serag, P. A. Richardson, and J. E. Everhart, "The role of diabetes in hepatocellular carcinoma: a case-control study among United States Veterans," American Journal of Gastroenterology, vol. 96, no. 8, pp. 2462-2467, 2001.

[57] Y. Fujino, T. Mizoue, N. Tokui, and T. Yoshimura, "Prospective study of diabetes mellitus and liver cancer in Japan," Diabetes/Metabolism Research and Reviews, vol. 17, no. 5, pp. 374-379, 2001.

[58] M. M. Hassan, S. A. Curley, D. Li et al., "Association of diabetes duration and diabetes treatment with the risk of hepatocellular carcinoma," Cancer, vol. 116, no. 8, pp. 1938-1946, 2010.

[59] H. Kuper, A. Tzonou, E. Kaklamani et al., "Tobacco smoking, alcohol consumption and their interaction in the causation of hepatocellular carcinoma," International Journal of Cancer, vol. 85, no. 4, pp. 498-502, 2000.

[60] H. E. Kuper, A. Tzonou, E. Kaklamani et al., "Hepatitis B and $\mathrm{C}$ viruses in the etiology of hepatocellular carcinoma; a study in Greece using third-generation assays," Cancer Causes and Control, vol. 11, no. 2, pp. 171-175, 2000.

[61] P. Lagiou, H. Kuper, S. O. Stuver, A. Tzonou, D. Trichopoulos, and H. O. Adami, "Role of diabetes mellitus in the etiology of hepatocellular carcinoma," Journal of the National Cancer Institute, vol. 92, no. 13, pp. 1096-1099, 2000. 
[62] E. Giovannucci, E. B. Rimm, M. J. Stampfer, G. A. Colditz, and W. C. Willett, "Diabetes mellitus and risk of prostate cancer (United States)," Cancer Causes and Control, vol. 9, no. 1, pp. 3-9, 1998.

[63] D. Li and J. L. Abbruzzese, "New strategies in pancreatic cancer: emerging epidemiologic and therapeutic concepts," Clinical Cancer Research, vol. 16, no. 17, pp. 4313-4318, 2010.

[64] D. Li, S. J. Yeung, M. M. Hassan, M. Konopleva, and J. L. Abbruzzese, "Antidiabetic therapies affect risk of pancreatic cancer," Gastroenterology, vol. 137, no. 2, pp. 482-488, 2009.

[65] L. Gullo, R. Pezzilli, A. M. Morselli-Labate et al., "Italian Pancreatic Cancer Study Group. Diabetes and the risk of pancreatic cancer," The New England Journal of Medicine, vol. 331, no. 2, pp. 81-84, 1994.

[66] S. T. Chari, C. L. Leibson, K. G. Rabe et al., "Pancreatic cancer-associated diabetes mellitus: prevalence and temporal association with diagnosis of cancer," Gastroenterology, vol. 134, no. 1, pp. 95-101, 2008.

[67] F. Wang, M. Herrington, J. Larsson, and J. Permert, "The relationship between diabetes and pancreatic cancer," Molecular Cancer, vol. 2, article 4, 2003.

[68] F. Wang, J. Larsson, A. Abdiu et al., "Dissociated secretion of islet amyloid polypeptide and insulin in serum- free culture media conditioned by human pancreatic adenocarcinoma cell lines," International Journal of Pancreatology, vol. 21, no. 2, pp. 157-164, 1997.

[69] P. M. Webb, M. Law, C. Varghese, and D. Forman, "Gastric cancer and Helicobacter pylori: a combined analysis of 12 case control studies nested within prospective cohorts," Gut, vol. 49, no. 3, pp. 347-353, 2001.

[70] S. Aydemir, T. Bayraktaroglu, M. Sert et al., "The effect of Helicobacter pylori on insulin resistance," Digestive Diseases and Sciences, vol. 50, no. 11, pp. 2090-2093, 2005.

[71] H. Yamagata, Y. Kiyohara, K. Aoyagi et al., "Impact of Helicobacter pylori infection on gastric cancer incidence in a general Japanese population: the Hisayama Study," Archives of Internal Medicine, vol. 160, no. 13, pp. 1962-1968, 2000.

[72] R. Gen, M. Demir, and H. Ataseven, "Effect of helicobacter pylori eradication on insulin resistance, serum lipids and low-grade inflammation," Southern Medical Journal, vol. 103, no. 3, pp. 190-196, 2010.

[73] A. I. Adler, N. S. Weiss, M. L. Kamb, and J. L. Lyon, "Is diabetes mellitus a risk factor for ovarian cancer? A casecontrol study in Utah and Washington (United States)," Cancer Causes and Control, vol. 7, no. 4, pp. 475-478, 1996.

[74] C. Rodriguez, A. V. Patel, A. M. Mondul, E. J. Jacobs, M. J. Thun, and E. E. Calle, "Diabetes and risk of prostate cancer in a prospective cohort of US men," American Journal of Epidemiology, vol. 161, no. 2, pp. 147-152, 2005.

[75] M. Anzo, L. J. Cobb, D. L. Hwang et al., "Targeted deletion of hepatic Igf1 in TRAMP mice leads to dramatic alterations in the circulating insulin-like growth factor axis but does not reduce tumor progression," Cancer Research, vol. 68, no. 9, pp. 3342-3349, 2008.

[76] G. D. Smith, M. Egger, M. J. Shipley, and M. G. Marmot, "Post-challenge glucose concentration, impaired glucose tolerance, diabetes, and cancer mortality in men," American Journal of Epidemiology, vol. 136, no. 9, pp. 1110-1114, 1992.

[77] P. Stattin, O. Björ, P. Ferrari et al., "Prospective study of hyperglycemia and cancer risk," Diabetes Care, vol. 30, no. 3, pp. 561-567, 2007.
[78] B. C. H. Chiu, S. M. Gapstur, P. Greenland, R. Wang, and A. Dyer, "Body mass index, abnormal glucose metabolism, and mortality from hematopoietic cancer," Cancer Epidemiology Biomarkers and Prevention, vol. 15, no. 12, pp. 2348-2354, 2006.

[79] J. M. M. Evans, L. A. Donnelly, A. M. Emslie-Smith, D. R. Alessi, and A. D. Morris, "Metformin and reduced risk of cancer in diabetic patients," British Medical Journal, vol. 330, no. 7503, pp. 1304-1305, 2005.

[80] S. L. Bowker, S. R. Majumdar, P. Veugelers, and J. A. Johnson, "Increased cancer-related mortality for patients with type 2 diabetes who use sulfonylureas or insulin," Diabetes Care, vol. 29, no. 2, pp. 254-258, 2006.

[81] M. Monami, C. Lamanna, D. Balzi, N. Marchionni, and E. Mannucci, "Sulphonylureas and cancer: a case-control study," Acta Diabetologica, vol. 46, no. 4, pp. 279-284, 2009.

[82] E. Mannucci, M. Monami, D. Balzi et al., "Doses of insulin and its analogues and cancer occurrence in insulin-treated type 2 diabetic patients," Diabetes Care, vol. 33, no. 9, pp. 1997-2003, 2010.

[83] A. Dejgaard, H. Lynggaard, J. Råstam, and M. Krogsgaard Thomsen, "No evidence of increased risk of malignancies in patients with diabetes treated with insulin detemir: a metaanalysis," Diabetologia, vol. 52, no. 12, pp. 2507-2512, 2009.

[84] P. D. Home and P. Lagarenne, "Combined randomised controlled trial experience of malignancies in studies using insulin glargine," Diabetologia, vol. 52, no. 12, pp. 2499-2506, 2009.

[85] Y. U. X. Yang, S. Hennessy, and J. D. Lewis, "Insulin therapy and colorectal cancer risk among type 2 diabetes mellitus patients," Gastroenterology, vol. 127, no. 4, pp. 1044-1050, 2004.

[86] V. Donadon, M. Balbi, P. Casarin, A. Vario, and A. Alberti, "Association between hepatocellular carcinoma and type 2 diabetes mellitus in Italy: potential role of insulin," World Journal of Gastroenterology, vol. 14, no. 37, pp. 5695-5700, 2008.

[87] L. G. Hemkens, U. Grouven, R. Bender et al., "Risk of malignancies in patients with diabetes treated with human insulin or insulin analogues: a cohort study," Diabetologia, vol. 52, no. 9, pp. 1732-1744, 2009.

[88] J. M. Jonasson, R. Ljung, M. Talbäck, B. Haglund, S. Gudbjörnsdòttir, and G. Steineck, "Insulin glargine use and short-term incidence of malignancies-a population-based follow-up study in Sweden," Diabetologia, vol. 52, no. 9, pp. 1745-1754, 2009.

[89] H. M. Colhoun, "Use of insulin glargine and cancer incidence in Scotland: a study from the Scottish diabetes research network epidemiology group," Diabetologia, vol. 52, no. 9, pp. 1755-1765, 2009.

[90] C. J. Currie, C. D. Poole, and E. A. M. Gale, "The influence of glucose-lowering therapies on cancer risk in type 2 diabetes," Diabetologia, vol. 52, no. 9, pp. 1766-1777, 2009.

[91] J. Rosenstock, V. Fonseca, J. B. McGill et al., "Similar risk of malignancy with insulin glargine and neutral protamine Hagedorn $(\mathrm{NPH})$ insulin in patients with type 2 diabetes: findings from a 5 year randomised, open-label study," Diabetologia, vol. 52, no. 9, pp. 1971-1973, 2009.

[92] K. L. Rensing, F. M. Houttuijn Bloemendaal, E. M. Weijers et al., "Could recombinant insulin compounds contribute to adenocarcinoma progression by stimulating local angiogenesis?" Diabetologia, vol. 53, no. 5, pp. 966-970, 2010. 
[93] E. Liefvendahl and H. J. Arnqvist, "Mitogenic effect of the insulin analogue glargine in malignant cells in comparison with insulin and IGF-I," Hormone and Metabolic Research, vol. 40, no. 6, pp. 369-374, 2008.

[94] V. Donadon, M. Balbi, M. Ghersetti et al., "Antidiabetic therapy and increased risk of hepatocellular carcinoma in chronic liver disease," World Journal of Gastroenterology, vol. 15, no. 20, pp. 2506-2511, 2009.

[95] D. Weinstein, M. Simon, E. Yehezkel, Z. Laron, and H. Werner, "Insulin analogues display IGF-I-like mitogenic and anti-apoptotic activities in cultured cancer cells," Diabetes/Metabolism Research and Reviews, vol. 25, no. 1, pp. 41-49, 2009.

[96] A. Shukla, J. Grisouard, V. Ehemann, A. Hermani, H. Enzmann, and D. Mayer, "Analysis of signaling pathways related to cell proliferation stimulated by insulin analogs in human mammary epithelial cell lines," Endocrine-Related Cancer, vol. 16, no. 2, pp. 429-441, 2009.

[97] D. Mayer, A. Shukla, and H. Enzmann, "Proliferative effects of insulin analogues on mammary epithelial cells," Archives of Physiology and Biochemistry, vol. 114, no. 1, pp. 38-44, 2008.

[98] S. L. Bowker, Y. Yasui, P. Veugelers, and J. A. Johnson, "Glucose-lowering agents and cancer mortality rates in type 2 diabetes: assessing effects of time-varying exposure," Diabetologia, vol. 53, no. 8, pp. 1631-1637, 2010.

[99] P. D. Home, S. E. Kahn, N. P. Jones, D. Noronha, H. BeckNielsen, and G. Viberti, "Experience of malignancies with oral glucose-lowering drugs in the randomised controlled ADOPT (A Diabetes Outcome Progression Trial) and RECORD (Rosiglitazone Evaluated for Cardiovascular Outcomes and Regulation of Glycaemia in Diabetes) clinical trials," Diabetologia, vol. 53, no. 9, pp. 1838-1845, 2010.

[100] J. M. M. Evans, S. A. Ogston, A. Emslie-Smith, and A. D. Morris, "Risk of mortality and adverse cardiovascular outcomes in type 2 diabetes: a comparison of patients treated with sulfonylureas and metformin," Diabetologia, vol. 49, no. 5, pp. 930-936, 2006.

[101] G. Libby, L. A. Donnelly, P. T. Donnan, D. R. Alessi, A. D. Morris, and J. M. M. Evans, "New users of metformin are at low risk of incident cancer: a cohort study among people with type 2 diabetes," Diabetes Care, vol. 32, no. 9, pp. 1620-1625, 2009.

[102] A. DeCensi, M. Puntoni, P. Goodwin et al., "Metformin and cancer risk in diabetic patients: a systematic review and meta-analysis," Cancer Prevention Research, vol. 3, no. 11, pp. 1451-1461, 2010.

[103] V. N. Anisimov, L. M. Berstein, P. A. Egormin et al., "Effect of metformin on life span and on the development of spontaneous mammary tumors in HER-2/neu transgenic mice," Experimental Gerontology, vol. 40, no. 8-9, pp. 685-693, 2005.

[104] V. N. Anisimov, P. A. Egormin, T. S. Piskunova et al., "Metformin extends life span of HeR-2/neu transgenic mice and in combination with melatonin inhibits growth of transplantable tumors in vivo," Cell Cycle, vol. 9, no. 1, pp. 188-197, 2010.

[105] L. A. Cantrell, C. Zhou, A. Mendivil, K. M. Malloy, P. A. Gehrig, and V. L. Bae-Jump, "Metformin is a potent inhibitor of endometrial cancer cell proliferation-implications for a novel treatment strategy," Gynecologic Oncology, vol. 116, no. 1, pp. 92-98, 2010.
[106] E. Rozengurt, J. Sinnett-Smith, and K. Kisfalvi, "Crosstalk between insulin/insulin-like growth factor-1 receptors and $\mathrm{G}$ protein-coupled receptor signaling systems: a novel target for the antidiabetic drug metformin in pancreatic cancer," Clinical Cancer Research, vol. 16, no. 9, pp. 2505-2511, 2010.

[107] A. Tomimoto, H. Endo, M. Sugiyama et al., "Metformin suppresses intestinal polyp growth in Apc mice," Cancer Science, vol. 99, no. 11, pp. 2136-2141, 2008.

[108] Y. Zhuang and W. K. Keith, "Cell cycle arrest in Metformin treated breast cancer cells involves activation of AMPK, downregulation of cyclin D1, and requires p27 or p21," Journal of Molecular Signaling, vol. 3, article 18, 2008.

[109] A. Majuri, M. Santaniemi, A. Kunnari et al., "Rosiglitazone treatment increases plasma levels of adiponectin and decreases levels of resistin in overweight women with PCOS: a randomized placebo-controlled study," European Journal of Endocrinology, vol. 156, no. 2, pp. 263-269, 2007.

[110] S. K. Vijay, M. Mishra, H. Kumar, and K. Tripathi, "Effect of pioglitazone and rosiglitazone on mediators of endothelial dysfunction, markers of angiogenesis and inflammatory cytokines in type-2 diabetes," Acta Diabetologica, vol. 46, no. 1, pp. 27-33, 2009.

[111] M. Monami, C. Lamanna, N. Marchionni, and E. Mannucci, "Rosiglitazone and risk of cancer: a meta-analysis of randomized clinical trials," Diabetes Care, vol. 31, no. 7, pp. 1455-1460, 2008.

[112] W. L. Read, M. Q. Baggstrom, P. M. Fracasso, and R. Govindan, "A phase I study of bexarotene and rosiglitazone in patients with refractory cancers," Chemotherapy, vol. 54, no. 3, pp. 236-241, 2008.

[113] G. A. Weaver, C. T. Tangel, J. A. Krause et al., "Biomarkers of human colonic cell growth are influenced differently by a history of colonic neoplasia and the consumption of acarbose," Journal of Nutrition, vol. 130, no. 11, pp. 2718-2725, 2000.

[114] T. Vilsbøll, "The effects of glucagon-like peptide-1 on the beta cell," Diabetes, Obesity and Metabolism, vol. 11, supplement 3, pp. 11-18, 2009.

[115] T. Salvatore, O. Carbonara, D. Cozzolino, R. Torella, and F. C. Sasso, "Progress in the oral treatment of type 2 diabetes: update on DPP-IV inhibitors," Current Diabetes Reviews, vol. 5, no. 2, pp. 92-101, 2009.

[116] T. Stulc and A. Sedo, "Inhibition of multifunctional dipeptidyl peptidase-IV: is there a risk of oncological and immunological adverse effects?" Diabetes Research and Clinical Practice, vol. 88, no. 2, pp. 125-131, 2010.

[117] J. A. Koehler and D. J. Drucker, "Activation of glucagon-like peptide-1 receptor signaling does not modify the growth or apoptosis of human pancreatic cancer cells," Diabetes, vol. 55, no. 5, pp. 1369-1379, 2006.

[118] L. B. Knudsen, L. W. Madsen, S. Andersen et al., "Glucagonlike peptide-1 receptor agonists activate rodent thyroid C-cells causing calcitonin release and C-cell proliferation," Endocrinology, vol. 151, no. 4, pp. 1473-1486, 2010. 


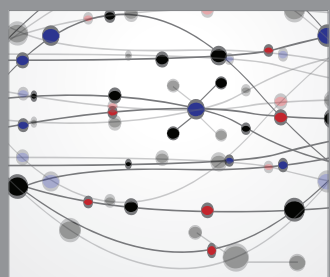

The Scientific World Journal
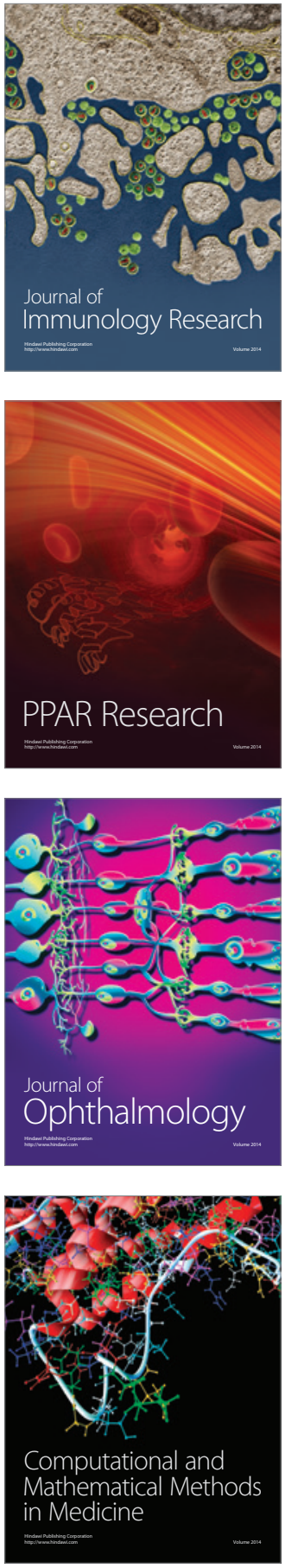

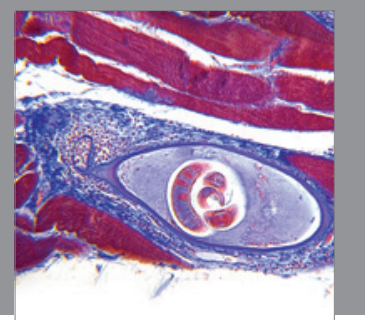

Gastroenterology

Research and Practice
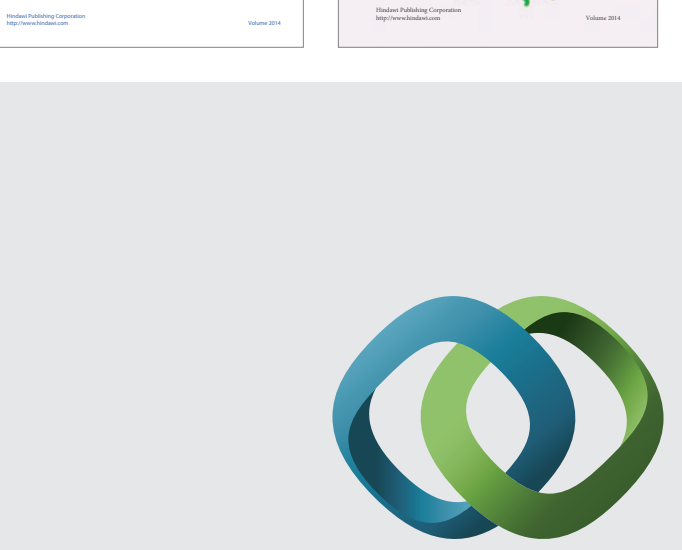

\section{Hindawi}

Submit your manuscripts at

http://www.hindawi.com
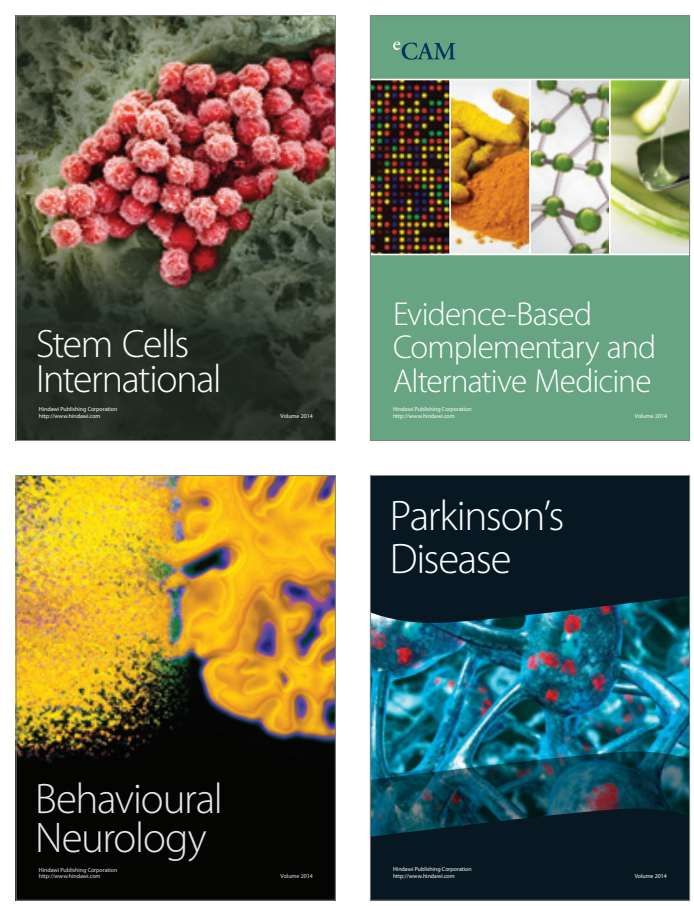

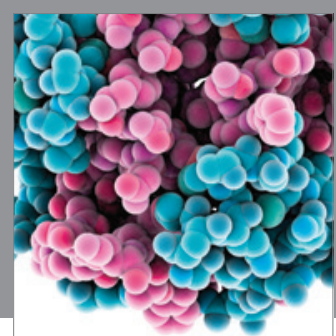

Journal of
Diabetes Research

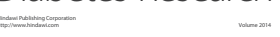

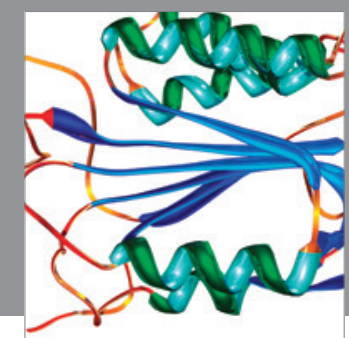

Disease Markers
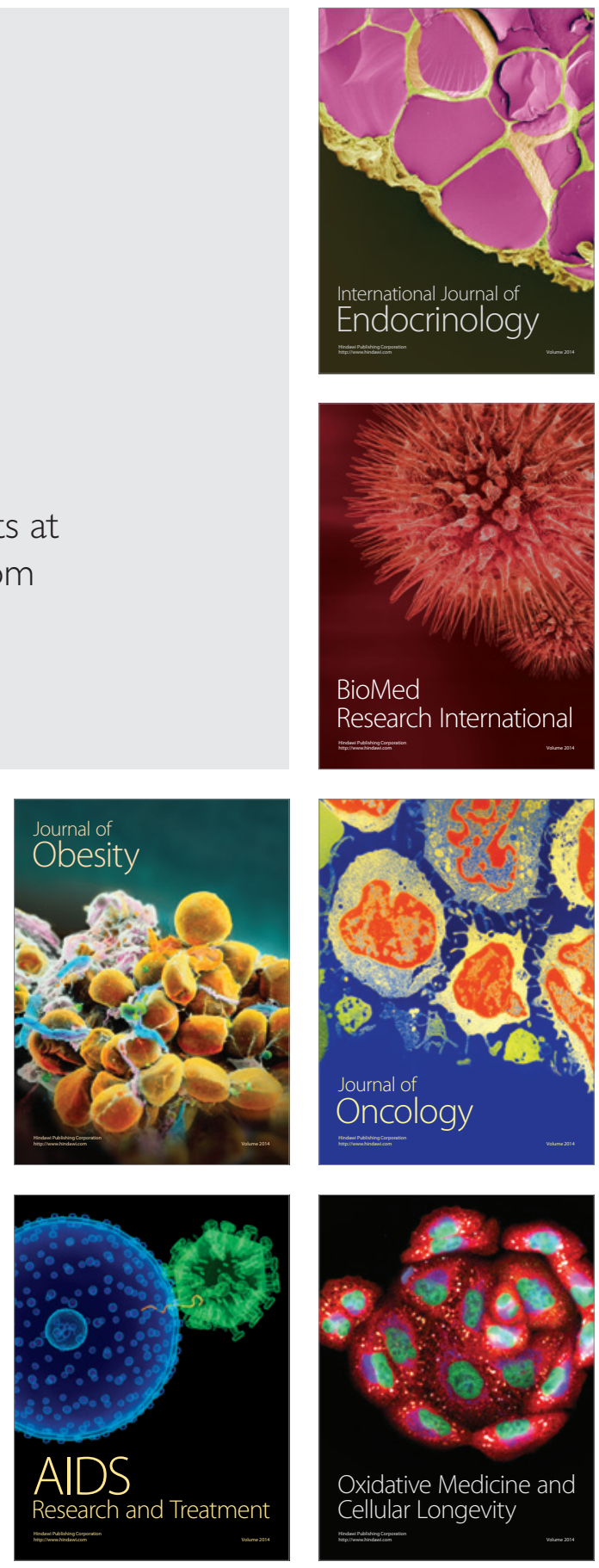